\title{
Photocatalytic hydrogen evolution systems constructed in cross-linked porous protein crystals
}

\section{Hiroyasu Tabe, Hikaru Takahashi, Takuya Shimoi, Satoshi Abe, Takafumi Ueno, Yusuke Yamada}

\begin{tabular}{|c|l|}
\hline \multicolumn{1}{|c|}{ Citation } & Applied Catalysis B: Environmental, 237: 1124-1129 \\
\hline Issue Date & 2018-12-05 \\
\hline Type & Journal Article \\
\hline Textversion & author \\
\hline Highlights & $\begin{array}{l}\text { ·A photocatalytic H_2 evolution system was constructed in cross-linked porous protein } \\
\text { crystals. } \\
\text { photosensitizers. } \\
\text { ·Selection of precursors of PtNPs is important for efficient H_2 evolution due to } \\
\text { protein-metal complex interactions. } \\
\text { ·Restricted growth of PtNPs within porous protein crystals enhances activity for } \\
\text { photocatalytic H_2 evolution. }\end{array}$ \\
\hline Rights & $\begin{array}{l}\text { C2018 Elsevier B.V. This manuscript version is made available under the } \\
\text { CC-BY-NC-ND 4.0 License. https://creativecommons.org/licenses/by־nc-nd/4.0/. } \\
\text { This is the accepted manuscript version. Please cite only the published version. The } \\
\text { article has been published in final form at https://doi.org/10.1016/j.apcatb.2018.01.046 }\end{array}$ \\
\hline DOI & \begin{tabular}{l} 
10.1016/j.apcatb.2018.01.046 \\
\hline
\end{tabular} \\
\hline
\end{tabular}

\author{
Self-Archiving by Author(s) \\ Placed on: Osaka City University
}

Hiroyasu Tabe, Hikaru Takahashi, Takuya Shimoi, Satoshi Abe, Takafumi Ueno and Yusuke Yamada (2018). Photocatalytic hydrogen evolution systems constructed in cross-linked porous protein crystals. Applied Catalysis B: Environmental. 237.1124-1129. doi:10.1016/j.apcatb.2018.01.046 
“有機 $\times$ 無機の新視点！ 卵由来のタンパク質と光エネルギーを利用した高効率な水素製造に成功！”.大阪市立 大学. https://www.osaka-cu.ac.jp/ja/news/2017/180209. （参照 2018-02-09）

\begin{tabular}{|c|c|}
\hline & $\begin{array}{l}\text { ・安価で入手しやすい鶏卵由来のリゾチーム結晶と、無尽蔵の光エネルギーを使って水素が製 } \\
\text { 造できる光触媒システムを構築 } \\
\text { ・高効率で水素を製造(水素の収率 } 76 \% \rightarrow 85 \%) \\
\text { ・リゾチーム結晶の内部間隙に機能性分子とナノ粒子を集積化することで、合理的な触媒シス } \\
\text { テムの設計が可能に }\end{array}$ \\
\hline & $\begin{array}{l}\text { ナノサイズの細孔をもつタンパク質(多孔性タンパク質結晶)の内部に、太陽光エネルギーを } \\
\text { 吸収する光増感剤分子と水素発生反応に対し触媒活性をもつ金属微粒子を近接させ集積化する } \\
\text { ことで、光エネルギーを利用して水素製造ができるシステムの構築に成功しました。 } \\
\text { この成果を利用することで、従来の光触媒系に比べて高い効率での光エネルギーの有効利用が } \\
\text { 可能になると期待されます。 }\end{array}$ \\
\hline & $\begin{array}{l}\text { 本研究では、天然に存在するタンパク質を有機多孔性材料として用いて、機能性分子とナ } \\
\text { ノ粒子を同時に集積化し、水素製造光触媒システムを高効率化する技術を開発しました。 } \\
\text { また、原子レベルでの構造観察の結果から、高効率化した理由も突き止めることができま } \\
\text { した。 } \\
\text { 今後、それぞれの化学反応の素反応過程に適した機能性分子や材料を任意の位置に配置 } \\
\text { できるタンパク質結晶を担体として利用することで、さまざまな用途に応じた触媒システ } \\
\text { ムを合理的に設計できるようになり、持続発展可能な社会の実現に繋がることが期待され } \\
\text { ます。 }\end{array}$ \\
\hline $\begin{array}{c}\text { 共同研究 } \\
\text { 資金等 }\end{array}$ & $\begin{array}{l}\text { 本研究は東京工業大学との共同研究で、下記の資金援助を得て実施されました。 } \\
\text { 公益信託 ENEOS 水素基金「メソ結晶内部の隣接間隙を利用した複合型光水素発生触媒」 } \\
\text { (研究代表者 : 山田 裕介) }\end{array}$ \\
\hline
\end{tabular}

Hiroyasu Tabe, Hikaru Takahashi, Takuya Shimoi, Satoshi Abe, Takafumi Ueno and Yusuke Yamada (2018). Photocatalytic hydrogen evolution systems constructed in cross-linked porous protein crystals. Applied Catalysis B: Environmental. 237.1124-1129. doi:10.1016/j.apcatb.2018.01.046 
Photocatalytic hydrogen evolution systems constructed in cross-linked porous protein crystals

Hiroyasu Tabe ${ }^{\mathrm{a}}$, Hikaru Takahashi ${ }^{\mathrm{a}}$, Takuya Shimoi ${ }^{\mathrm{b}}$, Satoshi Abe ${ }^{\mathrm{b}}$, Takafumi Ueno ${ }^{\mathrm{b}, *}$, Yusuke Yamada ${ }^{\mathrm{a}, *}$

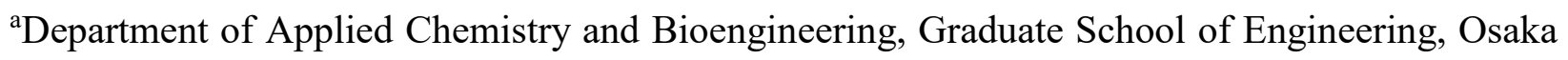
City University, Osaka 558-8585, Japan

${ }^{\mathrm{b}}$ School of Life Science and Technology, Tokyo Institute of Technology, 4259-B55, Nagatsutacho, Midori-ku, Yokohama 226-8501, Japan

* To whom correspondence should be addressed.

E-mail: tueno@bio.titech.ac.jp. (T. Ueno), ymd@ a-chem.eng.osaka-cu.ac.jp. (Y. Yamada) 


\begin{abstract}
Cross-linked hen egg white lysozyme crystals (CL-HEWL) have been employed as supports to construct heterogeneous catalysts for photocatalytic hydrogen $\left(\mathrm{H}_{2}\right)$ evolution, where rose bengal (RB) and $\mathrm{Pt}$ nanoparticles (PtNPs) acted as a photosensitizer and $\mathrm{H}_{2}$-evolution catalysts, respectively. Single-crystal X-ray structure analyses of the CL-HEWL immobilizing a precursor for PtNPs suggested that a coordination site of the precursor locates in immediate proximity to potential adsorption sites for RB. The accumulation of the components facilitated photo-induced electron transfer, resulting in efficient $\mathrm{H}_{2}$ evolution. These results suggest that porous protein crystals are promising platforms to periodically and rationally accumulate catalytic components by using molecular interactions.
\end{abstract}

Keywords: Heterogeneous catalysis; Photocatalysis; Hydrogen evolution; Protein crystal; Lysozyme 


\section{Introduction}

Bio-supramolecular structures utilizing proteins have attracted much attention to develop highly sophisticated functional materials [1-10], because multiple functional molecules can be immobilized simultaneously in a protein crystal by utilizing specific interaction with the functional groups of amino acids [11,12]. Additionally, interaction of side chains among proteins often induces self-assembled nanostructures available as nano-vessels for immobilization of metal clusters composed of multiple atoms [13-16]. Moreover, metal nanoparticles larger than the metal clusters can be immobilized in protein crystals where larger spaces are available among protein molecules aligned periodically [17-19]. Recently, protein crystals with a cross-link treatment have emerged as a robust porous material [20]. The pores can be provided by removal of solvent molecules from, so-called, solvent channels, in which metal complexes and organic compounds can be immobilized by selective interactions such as coordination, electrostatic interaction, hydrophobic interaction, etc, with the functional groups at the pore walls [21-24]. In fact, siteselective immobilization of metal nanoparticles by reduction of pre-organized metal complexes in solvent channels has been reported [14], indicating that sophisticated functional materials can be achieved by cooperative immobilization of functional molecules and metal nanoparticles in porous protein crystals.

Cooperative immobilization of a photoresponsible molecule and metal nanoparticles can provide solar energy conversion systems to produce high-energy compounds such as hydrogen $\left(\mathrm{H}_{2}\right)$ [25-28]. Efficient photocatalytic $\mathrm{H}_{2}$-evolution systems can be achieved by combination of several catalytic components including light-harvesting and charge-separation units and wateroxidation and reduction catalysts developed separately [29-38]. These components are usually combined in an appropriate solvent, however, back electron transfer between oxidation and 
reduction catalysts is hardly avoidable. Immobilization of these components with arrangement suitable for forward electron transfer can enhance the photocatalytic efficiency on the surfaces of a solid support such as mesoporous silica-alumina [34-37]. However, amorphous nature of mesoporous silica-alumina disturbs precise and periodical arrangement of components, which is necessary for efficient photocatalytic $\mathrm{H}_{2}$ evolution. In addition, anionic components are hardly immobilized on silica-alumina due to the electrostatic repulsion.

We report herein photocatalytic $\mathrm{H}_{2}$-evolution systems constructed in cross-linked hen egg white lysozyme crystals by immobilizing Pt nanoparticles (PtNPs) as $\mathrm{H}_{2}$-evolution catalysts in immediate proximity to an anionic photosensitizer molecule, rose bengal (RB). $\beta$ Dihydronicotinamide adenine dinucleotide (NADH) was employed as an electron donor, because irreversibly decomposing nature of $\mathrm{NADH}$ during the reaction can result in quantitative $\mathrm{H}_{2}$ evolution, allowing to evaluate the efficiency of the reaction systems by $\mathrm{H}_{2}$ yields [39]. Construction of photocatalytic $\mathrm{H}_{2}$ evolution systems composed of molecular $\mathrm{H}_{2}$-evolution catalyst and molecular photosensitizers in a viral protein particle has been reported [7], however, the small interior space allowed no co-immobilization of metal nanoparticles and photosensitizers. Larger inner spaces of porous protein crystals are necessary for co-immobilization of an organic photosensitizer and metal nanoparticles. Additionally, porous protein crystals immobilizing exogeneous molecules are stable in a photoreaction under visible light irradiation [40]. Thus, crosslinked hen egg white lysozyme crystals in the tetragonal form (CL-T-HEWL) and in the orthorhombic form (CL-O-HEWL) were employed as porous supports (Schemes 1a and 1b). The prepared catalysts were characterized by single-crystal X-ray structure analyses and TEM observations. Photocatalytic $\mathrm{H}_{2}$ evolution was performed in the presence of NADH under visible- 
light irradiation of a suspension containing the composite photocatalysts. The chemical structure of RB and the overall photocatalytic cycle

(a)

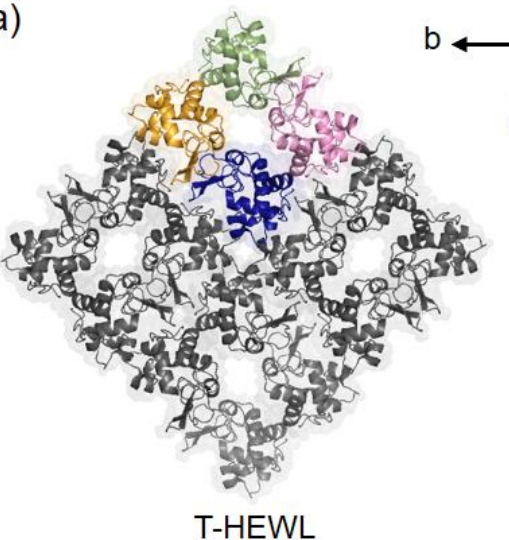

(c)

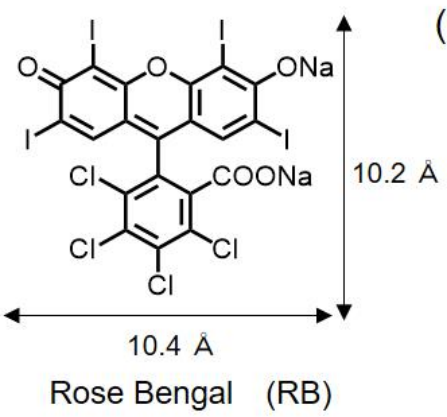

(d) (b)

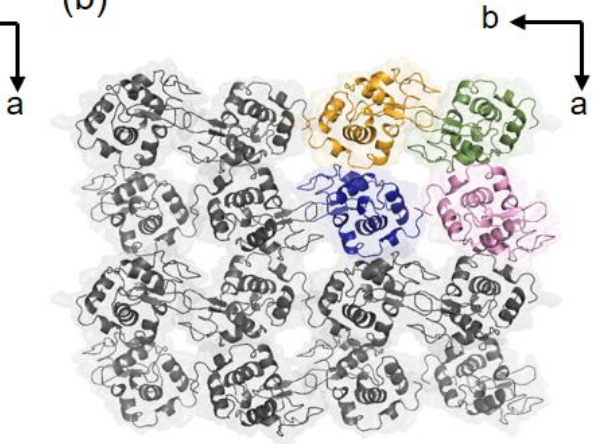

O-HEWL

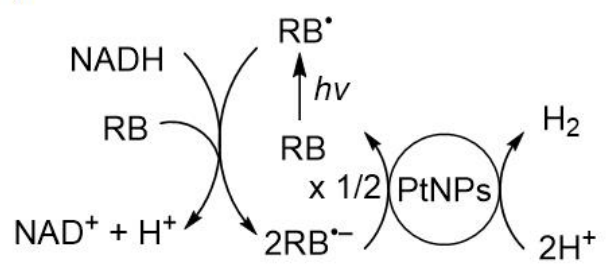

Scheme 1. Porous structure of HEWL crystals in (a) tetragonal form (T-HEWL) and (b) orthorhombic form (O-HEWL) from the Protein Data Bank (PDB), codes: 193L and 1BGI, respectively. (c) Chemical structure of rose bengal (RB) and (d) the overall photocatalytic cycle of $\mathrm{H}_{2}$ evolution.

are indicated in Schemes 1c and d, respectively. The accumulation of the components resulted in increasing the amount of evolved $\mathrm{H}_{2}$ to three times that of a homogeneous system without the HEWL crystals.

\section{Experimental section}

\subsection{Materials}


Hen egg white lysozyme (HEWL) was purchased from Sigma-Aldrich Co. LLC. Other reagents were purchased from Tokyo chemical industry Co., Ltd., Wako pure chemical, and Sigma-Aldrich and were used without further purification.

\subsection{Catalyst characterization}

UV-vis absorption spectra of rose bengal (RB) on each CL-T-HEWL composite were measured using a JASCO V-770 with an integrating sphere attachment. The atomic ratio of sulfur, iodine and platinum in each CL-T-HEWL composite was determined using a Shimadzu EDX-730 X-ray fluorescence spectrometer. Transmission electron microscope (TEM) images of PtNP@RB·CL-T-HEWL were obtained using a JEOL JEM-2100 equipped with a field-emission gun with an accelerating voltage of $200 \mathrm{kV}$. Thin pieces of PtNP@RB.CL-T-HEWL were fixed on a $\mathrm{Cu}$-mesh microgrid coated with an amorphous carbon supporting film.

\subsubsection{Single-crystal $X$-ray structure analysis}

The hanging drop vapor diffusion method was used to obtain HEWL crystals in the tetragonal form and in the orthorhombic form followed by the cross-linking treatment (CL-THEWL and CL-O-HEWL, respectively) [41,42]. These crystals were soaked in a drop of HEPES buffer (10 mM, pH 7.8) containing $\mathrm{RB}(10 \mathrm{mM})$ and $\mathrm{NaCl}(1.0 \mathrm{M})$ at room temperature for $24 \mathrm{~h}$ (RB.CL-T-HEWL and RB.CL-O-HEWL, respectively) followed by soaking in a drop of HEPES buffer (10 mM, pH 7.8) containing $\mathrm{H}_{2} \mathrm{PtCl}_{6} \cdot 6 \mathrm{H}_{2} \mathrm{O}(10 \mathrm{mM})$ and $\mathrm{NaCl}(1.0 \mathrm{M})$ for $24 \mathrm{~h}$. Although we attempted to soak crystals in buffer solution containing RB more than $10 \mathrm{mM}$, the crystals cracked during the incubation. Prior to data collection, crystals were continuously immersed in the precipitant solutions containing $10 \%$ and $25 \%(w / w)$ glycerol and subsequently frozen in liquid nitrogen. X-ray diffraction datasets for the sample were collected at $100 \mathrm{~K}$ at beamline BL26B1 at 
SPring- 8 using X-ray wavelengths of $1.0 \AA$. The data were processed with the program $H K L 2000$ [43].

The crystal parameters and the data collection statistics are summarized in Table S2. The structures were solved by molecular replacement with MOLREP [44] by using tetragonal and orthorhombic HEWL structures (PDB ID: 193L and 1BGI, respectively). Refinement of the protein structures was performed using REFMAC5 [45] in the CCP4 suite [46]. Rebuilding was performed using COOT [47] based on sigma-weighted $\left(2 \mathrm{~F}_{\mathrm{o}}-\mathrm{F}_{\mathrm{c}}\right)$ and $\left(\mathrm{F}_{\mathrm{o}}-\mathrm{F}_{\mathrm{c}}\right)$ electron density maps. After rigid-body refinement, the coordination structures of Pt binding sites were determined using anomalous Fourier difference maps and geometric parameters. Water molecules were positioned to fit residual $\left(\mathrm{F}_{\mathrm{o}}-\mathrm{F}_{\mathrm{c}}\right)$ density peaks with a lower cut-off of $3 \sigma$. The models were subjected to quality analysis during the various refinement stages with omit maps and RAMPAGE [48]. The refinement statistics are summarized in Table S1. Atomic coordinates for RB.CL-T-HEWL composite are deposited in the Protein Data Bank under accession number: 5YKY.

\subsection{Preparation of the composite of $C L-X-H E W L(X=T, O)$ with $R B(R B \cdot C L-X-H E W L)$}

HEWL crystals in the tetragonal form were obtained using a batch crystallization method followed by a cross-linking treatment according to the previously reported procedure (CL-THEWL) [41]. CL-T-HEWL (100 mg) was soaked in HEPES buffer (10 mM, pH 7.8, $50 \mathrm{~mL})$ containing rose bengal (RB, $1.0 \mathrm{mM})$ at room temperature for $12 \mathrm{~h}$ to immobilize $\mathrm{RB}$ in CL-THEWL. The composite of CL-T-HEWL with RB was obtained as dark red crystals (RB.CL-THEWL). The same procedure was applied to obtain the composite of cross-linked orthorhombic HEWL crystals with RB (RB·CL-O-HEWL) [42]. 
2.4. Photocatalytic hydrogen evolution by the composite of RB.CL-T-HEWL with Pt nanoparticles via photodeposition method

A phosphate buffer suspension (50 mM, pH 8.0, $2.0 \mathrm{~mL}$ ) containing RB. CL-T-HEWL ( 2.5 $\mathrm{mg}$ ), $\beta$-dihydronicotinamide adenine dinucleotide (NADH, $10 \mathrm{mM})$ and $\mathrm{H}_{2} \mathrm{PtCl}_{6} \cdot 6 \mathrm{H}_{2} \mathrm{O}(0.097$ $\mathrm{mM}$ ) was flushed with $\mathrm{N}_{2}$ gas for $40 \mathrm{~min}$. The suspension was then photoirradiated for a certain

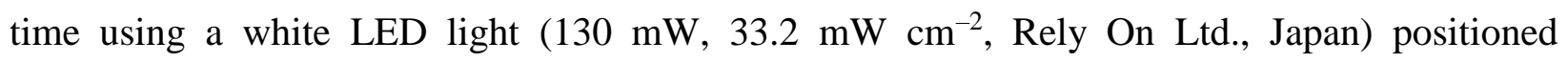
perpendicular to a cuvette at a distance of $3.0 \mathrm{~cm}$. While photoirradiation, RB.CL-T-HEWL gradually turned to black to form Pt nanoparticles (PtNPs) inside RB.CL-T-HEWL (PtNP@RB·CL-T-HEWL). Gas in a headspace was analyzed by Shimadzu GC-14B gas chromatography (detector: $\mathrm{TCD}$, column temperature: $80{ }^{\circ} \mathrm{C}$, column: active carbon with the particle size 60-80 mesh, carrier gas: $\mathrm{N}_{2}$ ) to determine the amount of evolved $\mathrm{H}_{2}$. After the $\mathrm{H}_{2}$ evolution reaction, buffer solution containing NADH $(200 \mathrm{mM}, 100 \mu \mathrm{L})$ was added to the cuvette for the next run to evaluate recycling performance of PtNP@RB·CL-T-HEWL.

2.5. Preparation of the composite of CL-T-HEWL with RB and Pt nanoparticles by a chemical reduction method

RB.CL-T-HEWL (50 mg) was soaked in an acetate buffer solution (100 mM, pH 8.0, 5.0 $\mathrm{mL}$ ) containing $\mathrm{H}_{2} \mathrm{PtCl}_{6} \cdot 6 \mathrm{H}_{2} \mathrm{O}(50 \mathrm{mM})$ for $30 \mathrm{~min}$, and then washed with water to remove unbound Pt complexes. CL-T-HEWL containing Pt complexes were soaked in an acetate buffer (100 mM, pH 4.8, $3.0 \mathrm{~mL}$ ) containing $\mathrm{NaBH}_{4}(250 \mathrm{mM})$ for $15 \mathrm{~min}$, then washed with water, and dried in vacuo (PtNP@RB·CL-T-HEWL(CR)).

\section{Results and discussion}




\subsection{Preparation and catalysis of composite photocatalysts}

RB was immobilized in CL-T-HEWL (RB·CL-T-HEWL) by the equilibrium adsorption [49]. The diffuse reflectance UV-vis absorption spectrum of RB-CL-T-HEWL evidenced absorption of RB (Fig. S1). The amount of adsorbed RB per unit cell of CL-T-HEWL was determined to be 0.64 based on the absorbance change at $548 \mathrm{~nm}$ of the RB mother liquor induced by the adding CL-T-HEWL (Fig. S2). This amount is comparable to that determined by X-ray fluorescence (XRF) spectroscopy based on the molar ratio of iodine in RB and sulfur in CL-T$\operatorname{HEWL}(0.45$, Table S1).

$\mathrm{RB} \cdot \mathrm{CL}-\mathrm{T}-\mathrm{HEWL}$ was soaked in a buffer solution containing $\mathrm{H}_{2} \mathrm{PtCl}_{6}(0.097 \mathrm{mM})$ as the precursor for Pt nanoparticles. The crystal structure of soaked RB·CL-T-HEWL was determined at $1.88 \AA$ A resolution (PDB ID: 5YKY; Fig. 1a, $1 \mathrm{~b}$ and Table S2). Two positions for immobilizing the Pt complexes were determined by the anomalous difference maps. A Pt complex at a $\mathrm{Pt}_{\mathrm{a}}$ position is bound to $\mathrm{N}^{\varepsilon}$ of His 15 with the $\mathrm{Pt}_{\mathrm{a}}-\mathrm{N}^{\varepsilon}$ length of $2.5 \AA$, as reported for HEWL crystals with other Pt-halide complexes (Fig. 1c) [50, 51]. Five $\mathrm{Cl}^{-}$ions bound to the $\mathrm{Pt}_{\mathrm{a}}$ ion fulfill the octahedral coordination. The other Pt complex in the form of $\left[\mathrm{Pt}_{b} \mathrm{Cl}_{6}\right]^{2-}$ was immobilized in the anion exchange site by the positively charged side chain of Lys 1 by electrostatic interaction where the distance between $\mathrm{Pt}_{\mathrm{b}}$ and $\mathrm{N}^{\alpha}$ of Lys1 was $3.4 \AA$ (Fig. 1d) [50]. Although unambiguous positions of $\mathrm{RB}$ were hardly determined, negatively charged $\mathrm{RB}$ is expected to be immobilized with positively charged side chains of Arg5, Arg 125 and Arg21 from an adjacent HEWL monomer in the solvent channel (Fig. $1 \mathrm{~b}$ and S3). The distance between a binding site for a Pt complex and the positively charged areas is enough close for electron transfer $(c a .2 \mathrm{~nm})$. Pt complexes were converted into PtNPs by the reduction with photogenerated $\mathrm{RB}^{\cdot-}$ followed by the photocatalytic 
reaction, because metal nanoparticles are grown in the region where pre-organized metal complexes are bound as reported previously [14].

(a)

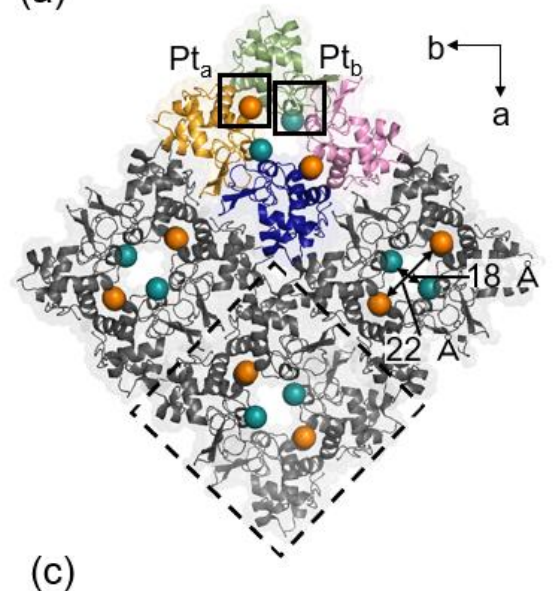

(c)

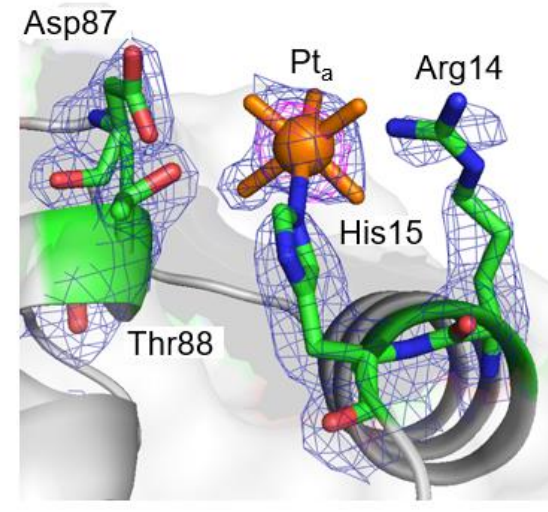

(b)

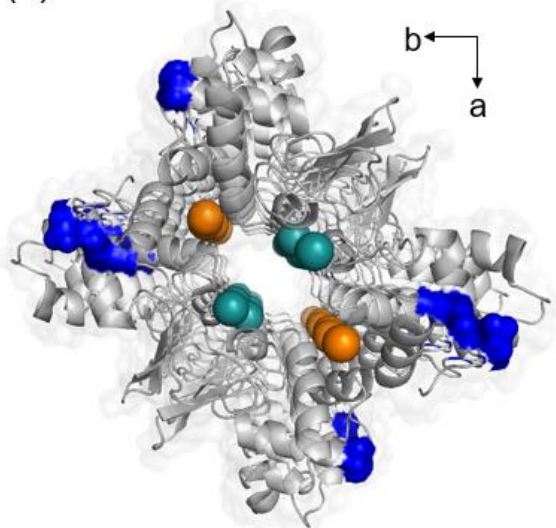

(d)

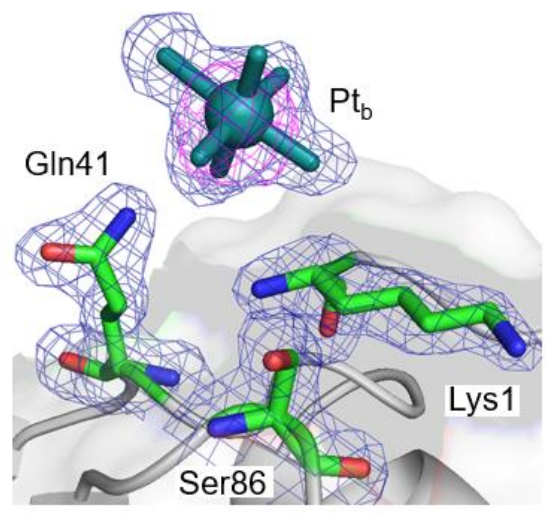

Fig. 1. (a) The overall structure of RB-CL-T-HEWL immobilizing pre-organized Pt-chloride complexes. The Pt atoms are represented by spheres. (b) Magnifications of a pore indicated by a dashed square in (a). Blue residues indicate positively charged area on the surface of solvent channels. (c, d) Magnifications of two Pt binding sites indicated by the black squares in (a). Anomalous difference Fourier maps at $3.0 \sigma$ indicate the positions of individual Pt atoms (magenta and turquois). Selected 2Fo-Fc electron-density maps at $1.0 \sigma$ are the deep blue mesh. Crystallographic images were produced by Pymol [52].

Photocatalytic $\mathrm{H}_{2}$ evolution was performed by the photoirradiation of a phosphate buffer dispersion ( $\mathrm{pH}$ 8.0) containing RB·CL-T-HEWL (2.5 mg), $\mathrm{H}_{2} \mathrm{PtCl}_{6}(0.097 \mathrm{mM})$ and NADH (10 $\mathrm{mM}$ ) as an electron donor as shown in Fig. 2 (solid line). PtNP@RB·CL-T-HEWL exhibited the activity for photocatalytic $\mathrm{H}_{2}$ evolution with the initial $\mathrm{H}_{2}$-evolution rate of $0.73 \mu \mathrm{mol} \mathrm{h}^{-1}$ and the 


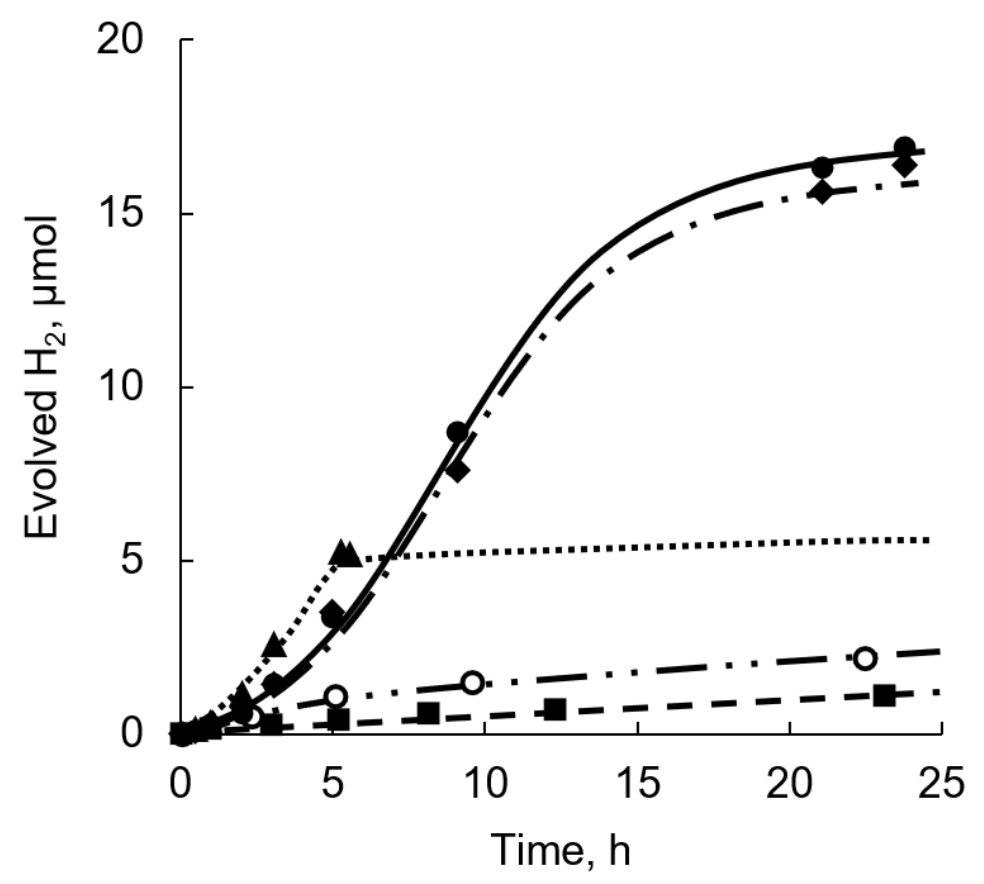

Fig. 2. Time courses of $\mathrm{H}_{2}$ evolution under photoirradiation $(\lambda>340 \mathrm{~nm})$ of a deaerated dispersion of a phosphate buffer (50 mM, pH 8.0, $2.0 \mathrm{~mL}$ ) containing PtNP@RB·CL-T-HEWL (•, solid line), PtNP@RB·CL-O-HEWL ( $\diamond$, dashed dotted line), PtNP@RB·CL-T-HEWL(CR) (घ, dashed line), homogeneous solution of $\mathrm{H}_{2} \mathrm{PtCl}_{6}$ with $\mathrm{RB}(\boldsymbol{\Delta}$, dotted line) and the mixture of homogeneous solution of $\mathrm{H}_{2} \mathrm{PtCl}_{6}$ with RB and CL-HEWL ( $\mathrm{O}$, dashed double-dotted line), in the presence of NADH $(10 \mathrm{mM})$.

$\mathrm{H}_{2}$ yield of $17 \mu \mathrm{mol}$ for $24 \mathrm{~h}$, suggesting that a photocatalytic system was successfully constructed in CL-T-HEWL. The $\mathrm{H}_{2}$ yield based on the used amount of $\mathrm{NADH}$ reached $85 \%$, where the turnover frequency (TOF) of evolved $\mathrm{H}_{2}$ per $\mathrm{RB}$ was $13 \mathrm{~h}^{-1}$. The $\mathrm{H}_{2}$ yield was higher than that (76\%) reported for a photocatalytic $\mathrm{H}_{2}$-evolution system using an assembly of monodispersed silica-alumina nanoparticles as a porous support together with 2-phenyl-4-(1naphthyl)quinolinium cation, PtNPs and $\mathrm{NADH}$ as a photosensitizer, an $\mathrm{H}_{2}$-evolution catalyst and an electron donor, respectively [36]. Moreover, the TOF was increased from those of catalytic 
systems constructed using a spherical mesoporous silica-alumina $\left(0.9 \mathrm{~h}^{-1}\right)$ or a porous assembly of monodispersed silica-alumina nanoparticles $\left(4.6 \mathrm{~h}^{-1}\right)$ as supports [36-38].

A homogeneous reaction system using a buffer solution containing PtNPs, RB and NADH without RB.CL-T-HEWL, which is similar to the method described in the previous report, resulted in lower $\mathrm{H}_{2}$ yield $(5.3 \mu \mathrm{mol}, 27 \%$, for $6 \mathrm{~h})$ than that with PtNP@RB.CL-T-HEWL although the initial $\mathrm{H}_{2}$-evolution rate is relatively high $\left(0.97 \mu \mathrm{mol} \mathrm{h}^{-1}\right.$, Fig. 2, dashed line) [53]. The mixture of PtNPs, RB, NADH and CL-HEWL in a buffer solution also showed the low activity for $\mathrm{H}_{2}$ evolution ( $2.2 \mu \mathrm{mol}, 11 \%$, for $23 \mathrm{~h}$, Fig. 2 , the dashed double-dotted line) compared with PtNP@RB·CL-T-HEWL. These results suggest that the immobilization of each component in a solvent channel of HEWL crystals enhanced the stability of the catalytic system. Slightly slower $\mathrm{H}_{2}$ evolution with CL-T-HEWL can be explained by slow diffusion of NADH in the solvent channels. The amounts of RB and Pt per HEWL monomer for PtNP@RB·CL-T-HEWL determined by XRF were 0.035 and 0.036 , respectively (Table S1). Formation and growth of PtNPs during the reaction were confirmed by a transmission electron microscope (TEM). PtNPs in the size of $c a .1 \mathrm{~nm}$ (Fig. S5a) on RB.CL-T-HEWL were observed soon after the induction period $(\sim 5 \mathrm{~h})$. Growing PtNPs with the size of $c a .2 \mathrm{~nm}$ were observed at the prolonged reaction time of $24 \mathrm{~h}$ (Fig. S5b). Formed PtNPs were well-dispersed throughout the crystals of RB.CL-THEWL and smaller than the size of solvent channels of CL-T-HEWL.

RB·CL-O-HEWL with PtNPs (PtNP@RB·CL-O-HEWL) also showed the activity for photocatalytic $\mathrm{H}_{2}$ evolution (Fig. 2, dotted dashed line). Single-crystal X-ray structure analysis of $\mathrm{RB} \cdot \mathrm{CL}-\mathrm{O}-\mathrm{HEWL}$ indicated that electron density originated from a $\mathrm{Pt}$ ion was found at the $\mathrm{Pt}_{\mathrm{a}}$ position while this density was too low to fit the models of a Pt-chloride complex (Fig. S4 and Table S2). The positively charged area around Arg5 and Arg125 from an adjacent HEWL 
monomer is located with separation distances of $c a .2 \mathrm{~nm}$ from $\mathrm{Pt}_{\mathrm{a}}$ (Fig. S4). Thus, the catalytic activity of PtNP@RB·CL-O-HEWL is comparable to that of PtNP@RB·CL-T-HEWL.

CL-T-HEWL with PtNPs was also prepared by chemical reduction (CR) of Pt complexes by $\mathrm{NaBH}_{4}$ according to a previously reported procedure (PtNP@RB·CL-T-HEWL(CR)) [23]. The amount of Pt per HEWL monomer determined by XRF is about 5 times higher than that of PtNP@RB·CL-T-HEWL (0.16, Table S1). However, only negligible amount of $\mathrm{H}_{2}(<1 \mu \mathrm{mol}$ in 12 h) was evolved with PtNP@RB·CL-T-HEWL(CR) (Fig. 2, dashed line). The TEM image in Fig. S5c showed that the particle size of PtNPs in PtNP@RB·CL-T-HEWL(CR) was as small as ca. $3 \mathrm{~nm}$. As previously reported, PtNPs generated by $\mathrm{CR}$ originated from pre-organized Pt ions in $\sim 10$ neighboring HEWL monomers [23]. Thus, PtNPs were immobilized irrespective of the positions of adsorbed RB. On the other hand, PtNPs generated by the reduction with photogenerated $\mathrm{RB}^{--}$were immobilized in immediate proximity to adsorbed $\mathrm{RB}$, where efficient electron transfer from photogenerated RB to PtNPs is possible.

\subsection{Recycling tests}

The $\mathrm{H}_{2}$ evolution lasted for more than $64 \mathrm{~h}$ by the successive addition of an aqueous NADH solution to the reaction solution containing PtNP@RB·CL-T-HEWL after $\mathrm{H}_{2}$ evolution ceased (Fig. 3). The yield at each run together with the initial $\mathrm{H}_{2}$-evolution rate was $17 \mu \mathrm{mol}(85 \%, 0.73$

$\left.\mu \mathrm{mol} \mathrm{h}{ }^{-1}\right), 11 \mu \mathrm{mol}\left(55 \%, 2.3 \mu \mathrm{mol} \mathrm{h}^{-1}\right)$ and $7 \mu \mathrm{mol}\left(35 \%, 0.94 \mu \mathrm{mol} \mathrm{h}^{-1}\right)$, indicating that the total turnover number exceeded $5.9 \times 10^{2}$. The induction period observed at the first run resulted from the PtNP formation. The RB/HEWL ratio of PtNP@RB·CL-T-HEWL determined by X-ray fluorescence spectroscopy (Table S1) decreased to 0.020 after the third run from that after the first run (0.035) due to partial leaching of RB . On the other hand, Pt/HEWL ratio after the third 


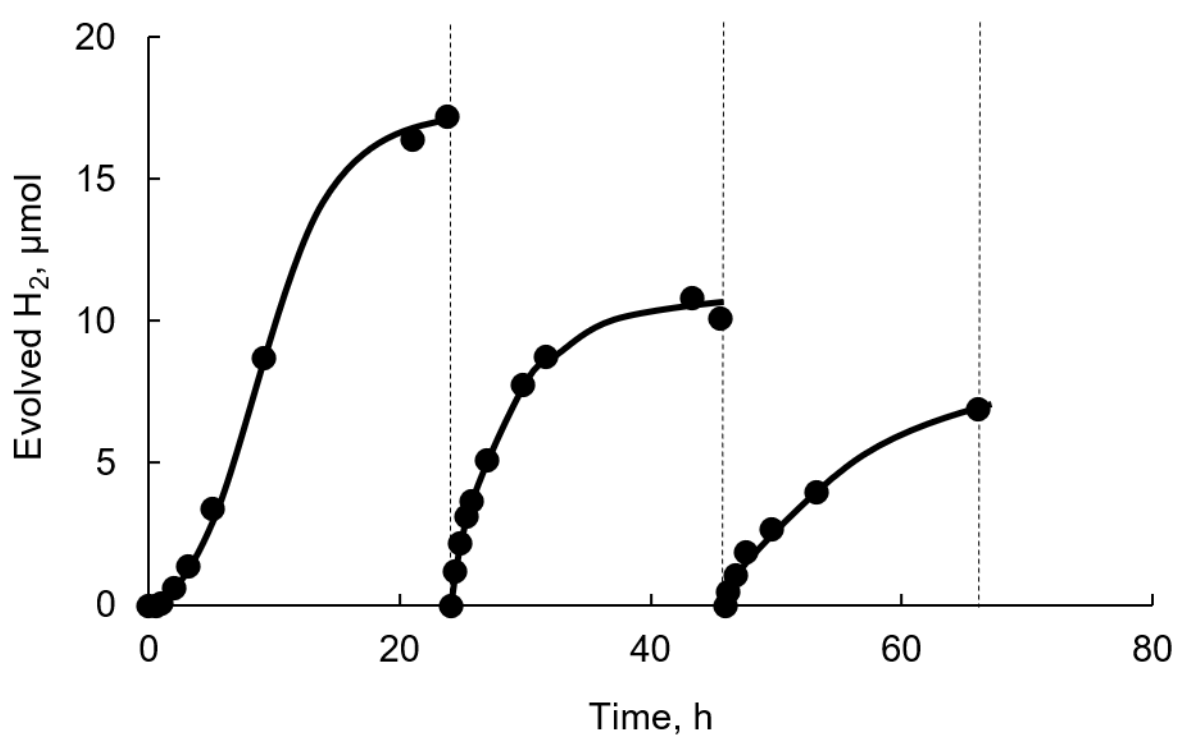

Fig. 3. Time courses of the photocatalytic $\mathrm{H}_{2}$ evolution under photoirradiation of a deaerated phosphate buffer $(50 \mathrm{mM}$, pH 8.0, $2.0 \mathrm{~mL})$ containing $\mathrm{H}_{2} \mathrm{PtCl}_{6}(0.097 \mathrm{mM})$, RB.CL-T-HEWL (2.5 $\mathrm{mg},[\mathrm{RB}]=0.40 \mathrm{mM})$ and $\mathrm{NADH}(10 \mathrm{mM})$ in three repetitive experiments.

run (0.046) increased by $29 \%$ based on that after the first run $(0.036)$. Thus, the spontaneous growth of PtNPs which prohibits the diffusion of NADH in the solvent channels and partial leaching of $\mathrm{RB}$ are reasons for deceleration of $\mathrm{H}_{2}$ evolution in repetitive runs.

\subsection{Precursor effect for composite photocatalysts}

The concentration effects of the Pt precursor in reaction solutions were examined ranging from 0.019 to $0.72 \mathrm{mM}$ (Fig. 4). When the concentration of $\mathrm{H}_{2} \mathrm{PtCl}_{6}$ was increased to $0.72 \mathrm{mM}$ from $0.097 \mathrm{mM}$, the initial reaction rate $\left(0.71 \mu \mathrm{mol} \mathrm{h}^{-1}\right.$, Fig. 4 , dashed line $)$ is comparable to that of the original concentration although the amount of evolved $\mathrm{H}_{2}$ was decreased to almost half $(9.0 \mu \mathrm{mol}$, $45 \%$, for $24 \mathrm{~h}$ ) compared with that of the original concentration. This result suggests that 


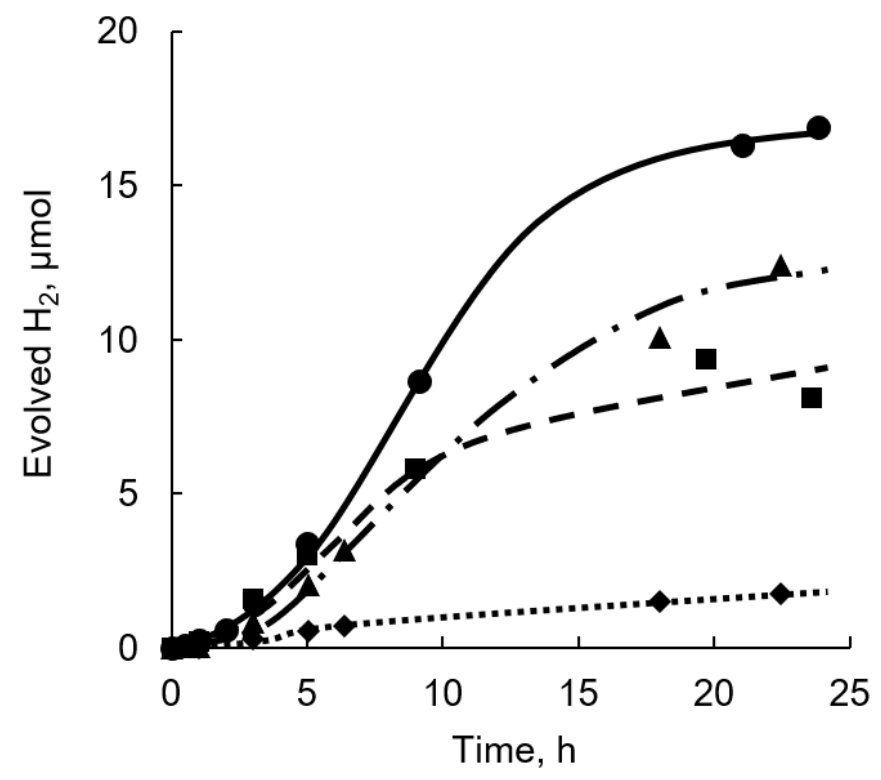

Fig. 4. Time courses of $\mathrm{H}_{2}$ evolution under photoirradiation (white light) of a phosphate buffer ( 50 $\mathrm{mM}, \mathrm{pH}$ 8.0, $2.0 \mathrm{~mL})$ containing NADH $(10 \mathrm{mM}), \mathrm{RB} \cdot \mathrm{CL}-\mathrm{T}-\mathrm{HEWL}(2.5 \mathrm{mg})$ and various $\mathrm{H}_{2} \mathrm{PtCl}_{6}$. Concentrations of $\mathrm{H}_{2} \mathrm{PtCl}_{6}: 0.019 \mathrm{mM}(\diamond$, dotted line), $0.048 \mathrm{mM}$ ( $\boldsymbol{\Lambda}$, dashed dotted line), 0.097 $\mathrm{mM}(\bullet$, solid line $)$ and $0.72 \mathrm{mM}(\boldsymbol{\bullet}$, dashed line $)$.

the overloaded $\mathrm{H}_{2} \mathrm{PtCl}_{6}$ formed larger PtNPs, which eventually prohibited the diffusion of NADH in the solvent channels. On the other hand, when the concentrations of $\mathrm{H}_{2} \mathrm{PtCl}_{6}$ were lower than $0.097 \mathrm{mM}$, the reaction rate and the amount of evolved $\mathrm{H}_{2}$ were increased as $\mathrm{H}_{2} \mathrm{PtCl}_{6}$ increases from (Fig. 4), where no larger PtNPs formed.

Various precursor complexes for PtNPs were employed to scrutinize their effect on the catalysis. Composite catalysts prepared with $\mathrm{K}_{2} \mathrm{PtCl}_{6}$ and $\mathrm{K}_{2} \mathrm{PtCl}_{4}$ exhibited high catalytic activity, because $\mathrm{PtCl}_{6}^{2-}$ and $\mathrm{PtCl}_{4}^{2-}$ can bind to His 15 and/or to the anion exchange site as reported previously (Fig. 5, solid and dotted lines) [23,54]. A composite catalyst prepared with cationic $\mathrm{Pt}\left(\mathrm{NH}_{3}\right)_{4} \mathrm{Cl}_{2}$ exhibited no activity for photocatalytic $\mathrm{H}_{2}$ evolution $(<1 \mu \mathrm{mol}$ in $5 \mathrm{~h}$, Fig. 5 , dashed line), resulting from no immobilization of Pt ions in CL-T-HEWL as evidenced by XRF measurements. Strong basicity of the $\mathrm{NH}_{3}$ ligands and electrostatic repulsion between an 


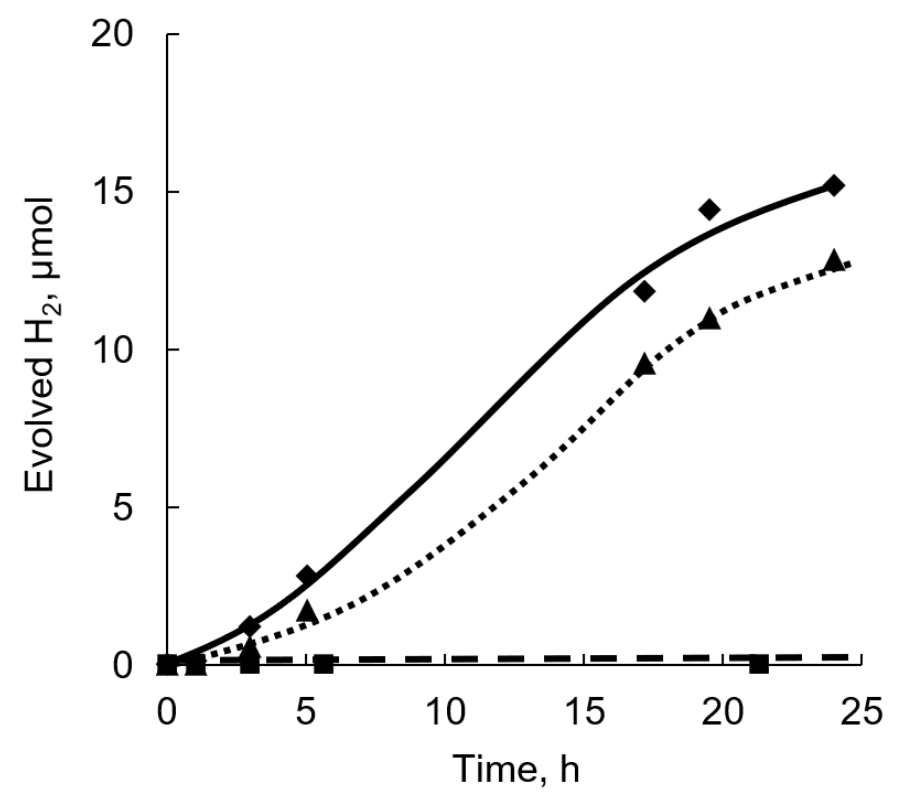

Fig. 5. Time courses of the photocatalytic $\mathrm{H}_{2}$ evolution under photoirradiation (white light) of a deaerated phosphate buffer $(50 \mathrm{mM}, \mathrm{pH} 8.0,2.0 \mathrm{~mL})$ containing NADH $(10 \mathrm{mM})$, RB·CL-THEWL $(2.5 \mathrm{mg}$ ) and various PtNP precursors $(0.097 \mathrm{mM})$. A precursor of PtNPs was chosen from

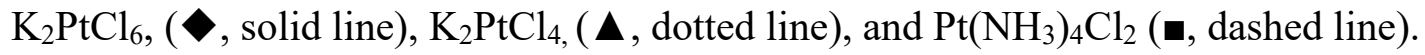

anion exchange site and $\left[\mathrm{Pt}\left(\mathrm{NH}_{3}\right)_{4}\right]^{2+}$ disturbed $\left[\mathrm{Pt}\left(\mathrm{NH}_{3}\right)_{4}\right]^{2+}$ from immobilization with neither histidine nor an anion exchange site.

\section{Conclusion}

We have successfully constructed a heterogeneous catalyst for photocatalytic $\mathrm{H}_{2}$ evolution using cross-linked HEWL crystals as a porous support. Rose bengal was immobilized in the solvent channels of HEWL crystals and $\mathrm{H}_{2}$-evolution catalysts, PtNPs, were obtained from preorganized Pt complexes in immediate proximity to rose bengal by the in-situ reduction of $\mathrm{Pt}$ complexes. The photosensitizer and the catalytic PtNPs were accumulated in the immediate proximity by utilizing coordination bonds and electrostatic interaction, resulting in efficient $\mathrm{H}_{2}$ evolution. More sophisticated catalytic systems can be provided by employing cross-linked porous 
protein crystals as supports where each component can be precisely arranged by molecular interactions.

\section{Acknowledgements}

We thank Mr. Masatsugu Ishimoto from Graduate School of Human Life Science, Osaka City University for his support throughout the TEM measurements. Synchrotron radiation experiments were conducted under the approval of 2017A2718 at SPring-8 BL26B1 with the support members.

\section{Funding sources}

This work was supported by ENEOS hydrogen trust fund (to Y. Yamada); and JSPS KAKENHI [grant numbers JP16H02268 (to Y. Yamada) and JP17H07020 (to H. Ttabe)].

\section{Appendix A. Supplementary content}

Supplementary contents associated with this article can be found, in the online version, at http://dx.doi.org/10.1016/j.cattod. XXXXX.

\section{References}

[1] F. Praetorius, H. Dietz, Self-assembly of genetically encoded DNA-protein hybrid nanoscale shapes, Science 355 (2017) eaam5488.

[2] J.G. Heddle, S. Chakraborti, K. Iwasaki, Natural and artificial protein cages: design, structure and therapeutic applications, Curr. Opin. Struct. Biol. 43 (2017) 148-155.

[3] Y. Suzuki, G. Cardone, D. Restrepo, P.D. Zavattieri, T.S. Baker, F.A. Tezcan, Selfassembly of coherently dynamic, auxetic, two-dimensional protein crystals, Nature 533 (2016) 369-373.

[4] J. Wang, K. Liu, R.R. Xing, X.H. Yan, Peptide self-assembly: thermodynamics and 
kinetics, Chem. Soc. Rev. 45 (2016) 5589-5604.

[5] Q. Luo, C.X. Hou, Y.S. Bai, R.B. Wang, J.Q. Liu, Protein assembly: versatile approaches to construct highly ordered nanostructures, Chem. Rev. 116 (2016) 13571-13632.

[6] P.C. Jordan, D.P. Patterson, K.N. Saboda, E.J. Edwards, H.M. Miettinen, G. Basu, M.C. Thielges, T. Douglas, Self-assembling biomolecular catalysts for hydrogen production, Nat. Chem. 8 (2016) 179-185.

[7] E. Edwards, R. Roychoudhury, B. Schwarz, P. Jordan, J. Lisher, M. Uchida, T. Douglas, Co-localization of catalysts within a protein cage leads to efficient photochemical NADH and/or hydrogen production, J. Mater. Chem. B 4 (2016) 5375-5384.

[8] Y.T. Lai, E. Reading, G.L. Hura, K.L. Tsai, A. Laganowsky, F.J. Asturias, J.A. Tainer, C.V. Robinson, T.O. Yeates, Structure of a designed protein cage that self-assembles into a highly porous cube Nat. Chem. 6 (2014) 1065-1071.

[9] N.P. King, J.B. Bale, W. Sheffler, D.E. McNamara, S. Gonen, T. Gonen, T.O. Yeates, D. Baker, Accurate design of co-assembling multi-component protein nanomaterials, Nature 510 (2014) 103-108.

[10] Y. Sano, A. Onoda, T. Hayashi, A hydrogenase model system based on the sequence of cytochrome $c$ : photochemical hydrogen evolution in aqueous media, Chem. Commun. 47 (2011) 8229-8231.

[11] J.B. Bailey, L. Zhang, J.A. Chiong, S. Ahn, F.A. Tezcan, Synthetic modularity of proteinmetal-organic frameworks, J. Am. Chem. Soc. 139 (2017) 8160-8166.

[12] J. Mikkila, E. Anaya-Plaza, V. Liljestrom, J.R. Caston, T. Torres, A. de la Escosura, M.A. Kostiainen, Hierarchical organization of organic dyes and protein cages into photoactive crystals, ACS Nano 10 (2016) 1565-1571.

[13] L. Messori, A. Merlino, Protein metalation by metal-based drugs: X-ray crystallography and mass spectrometry studies, Chem. Commun. 53 (2017) 11622-11633.

[14] B. Maity, S. Abe, T. Ueno, Observation of gold sub-nanocluster nucleation within a crystalline protein cage, Nat. Commun. 8 (2017) 14820.

[15] C. Molitor, A. Bijelic, A. Rompel, In situ formation of the first proteinogenically functionalized $\left[\mathrm{TeW}_{6} \mathrm{O}_{24} \mathrm{O}_{2}(\mathrm{Glu})\right]^{7-}$ structure reveals unprecedented chemical and geometrical features of the Anderson-type cluster, Chem. Commun. 52 (2016) 1228612289.

[16] L. Messori, T. Marzo, R.N.F. Sanches, Hanif-Ur-Rehman, D.D. Silva, A. Merlino, Unusual structural features in the lysozyme derivative of the tetrakis(acetato)chloridodiruthenium(II,III) complex, Angew. Chem. Int. Ed. 53 (2014) 6172-6175.

[17] M. Kunzle, T. Eckert, T. Beck, Binary protein crystals for the assembly of inorganic nanoparticle superlattices, J. Am. Chem. Soc. 138 (2016) 12731-12734.

[18] S. Abe, T. Ueno, Design of protein crystals in the development of solid biomaterials, RSC Adv. 5 (2015) 21366-21375.

[19] T. Ueno, Porous protein crystals as reaction vessels, Chem. Eur. J. 19 (2013) 9096-9102.

[20] A.L. Margolin, M.A. Navia, Protein crystals as novel catalytic materials, Angew. Chem. Int. Ed. 40 (2001) 2204-2222.

[21] M. Guli, E.M. Lambert, M. Li, S. Mann, Template-directed synthesis of nanoplasmonic arrays by intracrystalline metalization of cross-linked lysozyme crystals, Angew. Chem. Int. Ed. 49 (2010) 520-523.

[22] H. Tabe, S. Abe, T. Hikage, S. Kitagawa, T. Ueno, Porous protein crystals as catalytic 
vessels for organometallic complexes, Chem. Asian. J. 9 (2014) 1373-1378.

[23] S. Abe, M. Tsujimoto, K. Yoneda, M. Ohba, T. Hikage, M. Takano, S. Kitagawa, T. Ueno, Porous protein crystals as reaction vessels for controlling magnetic properties of nanoparticles, Small 8 (2012) 1314-1319.

[24] T. Koshiyama, M. Shirai, T. Hikage, H. Tabe, K. Tanaka, S. Kitagawa, T. Ueno, Postcrystal engineering of zinc-substituted myoglobin to construct a long-lived photoinduced charge-separation system, Angew. Chem. Int. Ed. 50 (2011) 4849-4852.

[25] M. Hansen, S. Troppmann, B. Konig, Artificial photosynthesis at dynamic self-assembled interfaces in water, Chem. Eur. J. 22 (2016) 58-72.

[26] S. Fukuzumi, Artificial photosynthetic systems for production of hydrogen, Curr. Opin. Chem. Biol. 25 (2015) 18-26.

[27] S. Berardi, S. Drouet, L. Francas, C. Gimbert-Surinach, M. Guttentag, C. Richmond, T. Stoll, A. Llobet, Molecular artificial photosynthesis, Chem. Soc. Rev. 43 (2014) 75017519.

[28] Z.J. Han, R. Eisenberg, Fuel from water: the photochemical generation of hydrogen from water, Acc. Chem. Res. 47 (2014) 2537-2544.

[29] Y.J. Yuan, Z.T. Yu, D.Q. Chen, Z.G. Zou, Metal-complex chromophores for solar hydrogen generation, Chem. Soc. Rev. 46 (2017) 603-631.

[30] C. Bachmann, B. Probst, M. Oberholzer, T. Fox, R. Alberto, Photocatalytic proton reduction with ruthenium and cobalt complexes immobilized on fumed reversed-phase silica, Chem. Sci. 7 (2016) 436-445.

[31] L.L. Duan, L. Wang, F.S. Li, F. Li, L.C. Sun, Highly efficient bioinspired molecular Ru water oxidation catalysts with negatively charged backbone ligands, Acc. Chem. Res. 48 (2015) 2084-2096.

[32] J. Li, Y.C. Wang, T. Zhou, H. Zhang, X.H. Sun, J. Tang, L.J. Zhang, A.M. Al-Enizi, Z.Q. Yang, G.F. Zheng, Nanoparticle superlattices as efficient bifunctional electrocatalysts for water splitting, J. Am. Chem. Soc. 137 (2015) 14305-14312.

[33] L.Z. Wu, B. Chen, Z.J. Li, C.H. Tung, Enhancement of the efficiency of photocatalytic reduction of protons to hydrogen via molecular assembly, Acc. Chem. Res. 47 (2014) 2177-2185.

[34] D. Kim, D.R. Whang, S.Y. Park, Self-healing of molecular catalyst and photosensitizer on metal-organic framework: robust molecular system for photocatalytic $\mathrm{H}_{2}$ evolution from water, J. Am. Chem. Soc. 138 (2016) 8698-8701.

[35] H.Q. Zhou, F. Yu, Y.F. Huang, J.Y. Sun, Z. Zhu, R.J. Nielsen, R. He, J.M. Bao, W.A. Goddard, S. Chen, Z.F. Ren, Efficient hydrogen evolution by ternary molybdenum sulfoselenide particles on self-standing porous nickel diselenide foam, Nat. Commun. 7 (2016) 12765.

[36] Y. Yamada, H. Tadokoro, M. Naqshbandi, J. Canning, M. J. Crossley, T. Suenobu, S. Fukuzumi, Nanofabrication of a solid-state, mesoporous nanoparticle composite for efficient photocatalytic hydrogen generation, ChemPlusChem 81 (2016) 521-525.

[37] Y. Yamada, H. Tadokoro, S. Fukuzumi, An effective preparation method of composite photocatalysts forhydrogen evolution using an organic photosensitizer and metalparticles assembled on alumina-silica, Catal. Today 278 (2016) 303-311.

[38] Y. Yamada, H. Tadokoro, S. Fukuzumi, Hybrid $\mathrm{H}_{2}$-evolution catalysts: in situ formation of $\mathrm{H}_{2}$-evolution catalysts from metal salts inside the mesopores of silica-alumina supporting an organic photosensitiser, RSC Adv. 3 (2013) 25677-25680. 
[39] H. Kotani, T. Ono, K. Ohkubo, S. Fukuzumi, Efficient photocatalytic hydrogen evolution without an electron mediator using a simple electron donor-acceptor dyad, Phys. Chem. Chem. Phys. 9 (2007) 1487-1492.

[40] H. Tabe, T. Shimoi, M. Boudes, S. Abe, F. Coulibaly, S. Kitagawa, H. Mori, T. Ueno, Photoactivatable $\mathrm{CO}$ release from engineered protein crystals to modulate NF- $\mathrm{KB}$ activation, Chem. Commun. 52 (2016) 4545-4548.

[41] M.C. Vaney, S. Maignan, M. RiesKautt, A. Ducruix, High-resolution structure (1.33 $\AA$ ) of a HEW lysozyme tetragonal crystal grown in the APCF apparatus. Data and structural comparison with a crystal grown under microgravity from SpaceHab-01 mission, Acta Crystallogr. D 52 (1996) 505-517.

[42] H. Oki, Y. Matsuura, H. Komatsu, A.A. Chernov, Refined structure of orthorhombic lysozyme crystallized at high temperature: correlation between morphology and intermolecular contacts, Acta Crystallogr. D 55 (1999) 114-121.

[43] Z. Otwinowski, W. Minor, Processing of X-ray diffraction data collected in oscillation mode, Method Enzymol. 276 (1997) 307-326.

[44] A. Vagin, A. Teplyakov, MOLREP: an automated program for molecular replacement, J. Appl. Crystallogr. 30 (1997) 1022-1025.

[45] A.A. Vagin, R.A. Steiner, A.A. Lebedev, L. Potterton, S. McNicholas, F. Long, G.N. Murshudov, REFMAC5 dictionary: organization of prior chemical knowledge and guidelines for its use, Acta Crystallogr. D 60 (2004) 2184-2195.

[46] E. Potterton, P. Briggs, M. Turkenburg, E. Dodson, A graphical user interface to the CCP4 program suite, Acta Crystallogr. D 59 (2003) 1131-1137.

[47] P. Emsley, K. Cowtan, Coot: model-building tools for molecular graphics, Acta Crystallogr. D 60 (2004) 2126-2132.

[48] R.A. Laskowski, M.W. Macarthur, D.S. Moss, J.M. Thornton, Procheck - a program to check the stereochemical quality of protein structures, J. Appl. Crystallogr. 26 (1993) 283291.

[49] A. Cvetkovic, A.J.J. Straathof, R. Krishna, L.A.M. van der Wielen, Adsorption of xanthene dyes by lysozyme crystals, Langmuir 21 (2005) 1475-1480.

[50] S.W. Tanley, L.V. Starkey, L. Lamplough, S. Kaenket, J.R. Helliwell, The binding of platinum hexahalides $(\mathrm{Cl}, \mathrm{Br}$ and $\mathrm{I})$ to hen egg-white lysozyme and the chemical transformation of the $\mathrm{PtI}_{6}$ octahedral complex to a $\mathrm{PtI}_{3}$ moiety bound to His15, Acta Crystallogr. F 70 (2014) 1132-1134.

[51] L. Messori, T. Marzo, C. Gabbiani, A.A. Valdes, A.G. Quiroga, A. Merino, Peculiar features in the crystal structure of the adduct formed between cis- $\mathrm{PtI}_{2}\left(\mathrm{NH}_{3}\right)_{2}$ and hen egg white lysozyme, Inorg. Chem. 52 (2013) 13827-13829.

[52] http://www.pymol.org/, (accessed 6 December 2017).

[53] X.J. Zhang, Z.L. Jin, Y.X. Li, S.B. Li, G.X. Lu, Efficient photocatalytic hydrogen evolution from water without an electron mediator over Pt-rose bengal catalysts, J. Phys. Chem. C, 113 (2009) 2630-2635.

[54] P.D. Sun, S. Radaev, M. Kattah, Generating isomorphous heavy-atom derivatives by a quick-soak method Part I: test cases, Acta Crystallogr. D, 58 (2002) 1092-1098. 